\title{
Gastric Microenvironment Enables Persistence of Helicobacter pylori: a Physician's Combat Towards Eradication and Directions for the
} Future

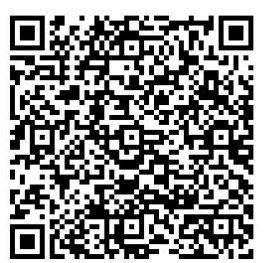

\author{
Ebinesh Arulnathan ${ }^{1 *}$, Bharath N. Lakshminarasimmaiah ${ }^{1}$, Harshitha J. Naik ${ }^{2}$
}

Infections caused by H. pylori are associated with multiple gastrointestinal diseases. To effectively reduce disease-related morbidity is to ensure the absolute eradication of the organism. The stomach plays a vital role in endowing survival strategies to $H$. pylori by inducing stress-hardening and cross-resistance, which helps H. pylori resist the acidic gastric ecosystem and administered antibiotics, respectively. An unstable gastric $\mathrm{pH}$ can cause phenotypic alteration in the bacteria, which induces a non-proliferative state and mkes them refractory to antibiotics. Moreover, the abundance of colonizing bacteria and the formation of biofilm aid in frequent mutual genetic transfers result in antibiotic resistance. Low gastric $\mathrm{pH}$ and rapid gastric emptying hinder the dissolution and distribution of antibiotics across the mucosal surface, which reduces the bioavailability and consequently favours the development of secondary resistance. The thick mucus lining of the stomach reduces the accessibility of administered antibiotic to all alcoves of $H$. pylori, which can be overcome by developing targeted drug delivery systems. Newer drug regimens have shown better eradication rates than standard triple therapy. However, regimens tailored based on conventional culture-sensitivity, molecular methods, or PPI pharmacogenomics are more effective. Probiotic supplementation can improve the treatment outcomes by increasing bacterial clearance and reducing adverse effects. A promising innovative technique would be to use $H$. pylori-specific bacteriophages for eradication. Additionally, oral vaccination against $H$. pylori is suggested to play a remarkable role in the prevention and treatment of infection, as shown in animal experiments. The most effective protective measures would be to improve environmental conditions and quality of life. This review provides insight into currently available treatment options, the challenges faced in successful treatment of $H$. pylori infections, and possible interventions to overcome these challenges in near future.

\section{INTRODUCTION}

The stomach, an assumed sterile surface free from microbial habitation (Bizzozero, 1893), was proven to be inhabited following the isolation and demonstration of Helicobacter pylori from the gastric biopsy samples by Warren and Marshall in 1983 (Warren and Marshall, 1983). Since then, medical literature databases have been inundated with thousands of studies, performed to determine the whereabouts of this bacterium every year. Consequently, we now discern the spectrum of gastrointestinal dysfunctions: chronic gastritis, peptic ulcer disease (PUD), gastric mucosa-associated

${ }^{1}$ Shridevi Institute of Medical Sciences and Research Hospital, Sira Rd, NH4, Tumakuru, Karnataka, 572106, India

${ }^{2}$ Department of Microbiology, Shridevi Institute of Medical Sciences and Research Hospital, Sira Rd, NH4, Tumakuru, Karnataka, 572106, India

*To whom correspondence should be addressed: ebineshjezreelsurgctvs@gmail.com

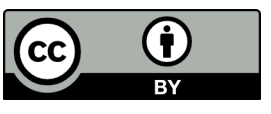

Except where otherwise noted, this work is licensed under https://creativecommons.org/licenses/by/4.0

doi:10.22186/jyi.35.6.97-105 lymphoid tissue (MALT) lymphoma, and gastric carcinoma (Malfertheiner et al., 2009; Kuipers, 1997; IARC monograph, 1994) as being associated with $H$. pylori infection. Efforts were also focused on instituting modalities to counter these pathologies in the form of reinforcing the gastric wall and killing the causative bacteria. Deep insight into the microbial structure, virulence factors, pathogenesis, and associated pathological states has directed scientists and clinical researchers to design compactly constituted drug regimens comprising antibiotics (amoxicillin, clarithromycin, metronidazole, levofloxacin, etc.), anti-secretory agents (PPIs and $\mathrm{H} 2$ blockers), and topical medications (colloidal bismuth preparations) for the eradication of $H$. pylori. These endeavours should simplify and expedite the process of the absolute eradication of H. pylori from the stomach. However, it proves to be a significant challenge. This bacterial endurance has been attributed to phenotypic and genotypic variations such as the development of drug resistance (Ebinesh and Kailash, 2016; Broutet et al., 2003) and the impotency of antimicrobial agents in the stomach (Vakil and Megraud, 2007; Bloom and Polak, 1980). The role of the stomach and its microenvironment in eradication failure (Table 1) and future prospects for successful eradication will be discussed.

DISCOVERY: HELICOBACTER PYRLORI AS A PATHOGEN 
Table 1. Challenges confronted in the eradication of $\boldsymbol{H}$. pylori.

Inborn and acquired characteristics of $\mathrm{H}$. pylori

1. Urease-mediated resistance to gastric acid that results in stress hardening

2. Chronic exposure to acid stress that induces cross resistance to antibiotics

3. Presence of bacteria along the mucosal surface and inside the epithelial cells

4. Heavy inoculum phenomenon

5. Stress-induced phenotypic resistance by survival as a slow grower (dormant form)

6. Biofilm formation and resultant drug resistance

Influence of stomach on therapeutic outcomes

1. Poor bioavailability of acid labile antibiotic due to low gastric $\mathrm{pH}$

2. Thick mucus lining which prevents access to all niches of bacterial resistance

3. Inducing secondary drug resistance due to reduction in bioavailability and area of distribution

4. Fast gastric emptying resulting in reduced duration of action

It was believed that the microenvironment of stomach was unsuitable for microbial existence (Bizzozero, 1893). Towards the end of 19th century, few scientists recorded the occurrence of spiralshaped bacilli in the stomach of animals (Bizzozero, 1893), following which a parallel observation was made in the stomach of humans suffering from peptic ulcer disease (Pel, 1899). Considering these spiral-shaped bacteria to be the cause of PUD, the patients underwent treatment with high doses of bismuth (Pel, 1899), which is one of the first known antimicrobial compounds. However, the idea that PUD was caused by these bacteria was disproven due to the presence of these spiral-shaped bacteria in the stomach of healthy individuals (Kusters et al., 2006). In the late 20th century, a series of remarkable experiments were staged by Warren and Marshall to demonstrate, isolate, and characterize the properties of this bacterium (Marshall et al., 1987; Marshall et al., 1985; Marshall et al., 1985; Marshall and Warren, 1984). In 1987, Marshall et al. and Morris and Nicholeson described an acute gastric inflammation and a long-standing gastritis respectively following autoingestion of $H$. pylori. In 1991, Morris again recorded a longstanding gastritis in human participants that was treated successfully with doxycycline and bismuth subsalicylate (Morris et al., 1991). Initially, this spiral-shaped bacterium was named "gastric Campylobacter- like organism" or "Campylobacter pyloridis". Goodwin (Godwin et al., 1989) described the divergent properties of the genus Campylobacter, after which it was termed "Helicobacter pylori".

\section{CURRENT MANAGEMENT OF H. PYLORI INFECTIONS}

Extensive scientific investigations have ascertained a direct association of $H$. pylori as the causative agent for chronic gastritis, PUD and gastric malignancies. Chronic gastritis was the first sequel of colonization, followed by PUD and malignancies. It should also be noted that $H$. pylori-associated gastroduodenal disease impart a high incidence of relapse (Rauwss and Tygat, 1990; Axon, 1991) which further enhances the jeopardy of developing a malignancy. IARC has classified $H$. pylori as a group 1 carcinogen (Testerman and Morris, 2014) which also encompasses radiations and smoking, accounting for $25 \%$ of all infection-associated malignancies and $5.5 \%$ of all cancers (Mbulaiteye et al., 2009). An absolute eradication will certify a colossal drop in $H$. pylori-associated morbidity and mortality. Bearing this fact in mind, European (Malfertheiner et al., 2002) and Canadian (Hunt et al., 1999) guidelines endorsed a "triple therapy regimen," roping in amoxicillin/ metronidazole, clarithromycin, and a proton pump inhibitor (PPI) for a scheduled period of 14 days and was once widely adopted across the globe (Hoffman and David, 2001) to eradicate the bacteria. Owing to the emergence of drug resistance in the recent years, triple therapy regimen is recommended for regions with a resistance rate of less than $20 \%$ and with susceptibility to clarithromycin infections (Malfertheiner et al., 2007). Greater frequency of drug resistance is generally encountered in Africa and East Asia, which is hypothesized to be a result of prevalence of multiple genotypic variant strains (Kaleb et al., 2007; Graham et al., 2009). Recently, various new drug regimens (incorporating antibiotics such as amoxicillin, metronidazole, clarithromycin, rifabutin, levofloxacin and furazolidone) have been introduced and are being increasingly utilized (Basu et al., 2011; Hsu et al., 2008). The newer drug regimens comprise of four first-line regimens (sequential, concomitant, bismuth-containing quadruple and hybrid regimens), two second-line regimens (bismuth-containing quadruple and levofloxacin-based regimens) and three third-line regimens (levofloxacin-based quadruple, rifabuti-based quadruple, and furazolidone-based quadruple regimens). The latter of which surpassed the standard triple regimen therapy in terms of eradication rates (Chuah et al., 2011; Gisbert et al., 2010; Wu et al., 2010; Malfertheiner et al., 2012; O'Morain et al., 2003; Laine et al., 2003; Phillips et al., 2001; Chey et al., 2007; Nishizawa et al., 2009; Van Der Poorten and Katelaris, 2007; M'egraud and Lehours, 2007). Though the prevalence of drug resistance exhibits worldwide diversity, according to a systematic review by Francesco and colleagues (Francesco et al., 2010), the global prevalence of resistance in H. pylori to clarithromycin, metronidazole, amoxicillin, tetracycline, levofloxacin and rifabutin was estimated to be $17.2 \%, 26.7 \%, 11.2 \%, 5.9 \%, 16.9 \%$ and $1.4 \%$, respectively, while multidrug resistance was $9.6 \%$. The surge in $H$. pylori's drug resistance is a consequence of the widespread use of agents like amoxicillin and clarithromycin for respiratory tract infections (M'egraud, 2004) and is also correlated with increased antibiotic consumption (Perez Aldana et al., 2002). This has intensified the antibiotic resistance burden, which has been a major contributor to the failure to eradicate H. pylori.

\section{INHERENT AND ACQUIRED POTENTIALS OF H. PYLO- $R I$ THAT INFLUENCE THERAPEUTIC OUTCOMES}

A conspicuous element of the H. pylori's survival strategies is its 
ability to resist the stomach's high acidity despite it being nonacidophilic. Pyrosequencing of the small unit 16sRNA has led provided insight on normal gut flora and has established the predominance of $H$. pylori in the stomach (Necchi et al., 2007; Friedrich, 2008). The average recorded $\mathrm{pH}$ of the stomach is 1.4 (Bloom and Polak, 1980), but it is said to vary somewhere between $\mathrm{pH}$ 4 and 6.5 (McLauchlan et al., 1989). Occasional "acid shocks", or transients peaks of acidity, are known to occur (Schade et al., 1994). Though the urease enzyme is believed to confer acid resistance necessary for survival (Burne and Chen, 2000), it does not aid the bacteria in withstanding acid shock (Bijlsma et al., 2000; Stingl et al., 2002). Hence, varying $\mathrm{pHs}$ provoke a perturbation in the spatial alignment of the bacteria, promoting resistance (Schreiber et al., 2004). It may also be a consequence of stress. Acidic $\mathrm{pHs}$ of $4-6.5$ (normal gastric $\mathrm{pH}$ ) is a sublethal environmental stress which, during prolonged exposure, induces the production of stress proteins that protect the bacteria from stress, stress hardening, and cross resistance. Stress hardening is a phenomenon by which repeated or prolonged exposure to sublethal levels of some form of stress makes the bacteria resistant to even lethal levels of the same stress (Rowan, 1999). This phenomenon holds true for H. pylori's resistance to acid shocks, since the bacteria has been in contact with a sublethal acidic $\mathrm{pH}(4-6.5)$ for a long duration, it also develops resistance to the lethal $\mathrm{pH}$ levels ( 1 - 3.5 during acid shocks). Moreover, it renders the bacteria resilient to other forms of stress including antibiotics (McDowell, 2004; Bremer and Kramer, 2000; Hastings et al., 2004; Ebinesh et al, 2018), making them cross-resistant (Alekshun and Levy, 1997; Archer, 1996; Ma et al., 1995; Velkov et al., 1999). These phenotypic variations are due to stress-induced genomic plasticity, causing an increase in the frequency of random mutagenesis and gene transfer (Ebinesh et al., 2018; Velkov et al., 1999; Gougeon et al., 2000; McMahon et al., 2007). Another phenotypic variation recorded in H. pylori is its ability to oscillate between an active proliferative state and a dormant non-proliferative state in pace with the microenvironment. As most of the antibiotics are only active against actively replicating clone of bacteria, this phenotypic resistant state serves as another impediment for eradication (Scott et al., 1998).

H. pylori are uniformly distributed throughout the surface of gastric mucosa (Genta et al., 1994) which indicates a heavy bacterial load (Graham, 1998). Basic statistical application reveals that a high bacterial load is associated with a high rate of spontaneous mutation and a healthy drug resistant clone (innate and acquired resistance) (Graham DY and Fischbach L, 2010). Moreover, a large inoculum would also reduce the efficacy of administered antibiotic agent (Genta RM et al, 1994). H. pylori possess the ability to form biofilms, which makes eradication tougher by facilitating gene transfer and thus harnessing drug resistance (M'egraud $F$ et al, 1991). Presence of multiple adhesins for binding to mucosal epithelial cells (Graham DY, 1998) and both intra and extra cellular habituation of $H$. pylori (Engstrand L et al, 1997) increases the risk of eradication failure by expanding the degree of virulence and being inaccessible to antibiotic agents respectively (the latter will be discussed extensively under the next heading).

\section{THE STOMACH AND THERAPEUTICS: THE RELATION- SHIP AND ITS IMPLICATIONS}

An important factor that challenges absolute eradication is the fact that the stomach is $H$. pylori's habitat. A major determinant of the outcome of antibiotic therapy is the drug concentration at the site of action. The $\mathrm{pH}$ of the stomach is lower than the optimal $\mathrm{pH}$ for the action of drugs, thus limiting the diffusion and distribution of antimicrobial agent across the mucosal surface (Vakil and Megraud, 2007; Bloom and Polak, 1980; Graham and Borsch, 1990; Borsch and Graham, 1991; Hunt, 1993). Hence, the bioavailability of antibiotic agents decreases and the bacteria are exposed to sublethal doses (Graham, 1998) of antibiotics, culminating in secondary drug resistance. The development of secondary resistance to clarithromycin and metronidazole has been known to impair the progress and outcome of therapy (Boltin et al., 2015). Low gastric $\mathrm{pH}$ is a major barrier to the action of many drugs especially those like clarithromycin, which are acid labile. However, the action of tetracycline is instead supplemented by acidic $\mathrm{pH}$ and that of bismuth and metronidazole is not influenced (Grayson et al., 1989; Goodwin and McNulty, 1992). Erratic gastric pH bestows a state of phenotypical resistance upon the bacteria where the bacilli do not multiply and thus the antibiotics seldom work (Scott et al., 1998). Therefore, the co-administration of acid secretion inhibitors (like PPIs and H2 blockers) should result in a decrease in eradication failure (Moayyedi et al., 1995; Unge et al., 1989).

H. pylori are known to reside on the mucosal surface and inside the epithelial cells (Engstrand et al., 1997). Persistence of the bacilli along the epithelial surface leaves a theoretical advantage for rapid eradication, as the inaccessibility can be attributed to the presence of thick mucus membrane along the mucosal surface (Wu et al., 2012). The active flow of the antibiotic across the mucus lining is needed to ensure eradication (Midolo et al., 1996), which when compromised, results in recolonization and reinfection that further complicates the issue (Atherton et al., 1995).

Gastric emptying and the distribution of antibiotics across the mucosa are the two other parameters that determine post-therapeutic outcomes and can be maneuvered (Graham, 1998). The administration of a drug with food delays gastric emptying, provides wider distribution, and dilutes acidity (Graham and Borsch, 1990; Graham and Evans, 1990). However, a major drawback in administering antibiotics with food is the unpredictable molecular interactions and possible reduction in the local availability of the antibiotic. The grinding action of stomach during digestion generates friction between the gastric mucosa and the bulk of food, bringing about mucosal desquamation and mucus secretion, thereby exposing the bacteria to a higher concentration of the drug and thus enhancing antimicrobial activity (Grant et al., 1953; Williem, 1988). The form of the administered drug influences the distribution of the drug throughout the mucosal surface. Capsules may get lodged in the rugal folds of the stomach and may only produce a local action (Graham, 1998). Tablets have a relatively better dis- 
solution and distribution. Liquid forms have the highest surface area of distribution, but are emptied faster into the duodenum. Tablets and capsules can be designed for a sustained depot delivery while liquid forms cannot be designed to be extended release forms (Goodwin and McNulty, 1992). Colloidal bismuth preparations bind to the mucus and give off extended and sustained action which renders them potent adjuvants especially in case of managing reinfection or relapse. Unfortunately, the hypothetical advantage of substituting liquid formulation of amoxicillin for capsules was documented to possess no difference in outcome (Marshall, 1993), after which no attempts were directed to evaluate the efficacy of other antibiotics.

\section{IMPENDING PROSPECTS AND FUTURE DIRECTIONS}

In comparison to the standard triple therapy, newer regimens are now known to yield higher eradication rates despite their specific disadvantages (Hsu et al., 2011; Malfertheiner et al., 2011; Liou et al., 2010; Toracchio et al., 2005). Other strategies that may work would be pretreatment drug sensitivity-based tailored regimens, bacteriophage-mediated selective clearance, probiotic supplementation, and the development of potent vaccines.

\section{New drug regimens}

The newer drug regimens promise improved treatment outcomes. Most of the novel drug regimens are levofloxacin-based, meaning they are relatively more efficacious (Liou et al., 2010). Widespread use of levofloxacin for other indications might result in pervasive resistance. Hence, levofloxacin-based regimens should be reserved for second-line treatment only. Rifabutin is a rifamycin-S derivative which has proven to potentially act against $H$. pylori activity (Van Der Poorten and Katelaris, 2007; Toracchio et al., 2005). Extensive non-judicial use of rifabutin also results in the development of resistance. Furthermore, it is also known to induce cross resistance against rifampin (a potent anti-tubercular drug) (Heep et al., 1999; Suzuki et al., 2009; Glocker et al., 2007) which puts the developing nations with high tuberculosis prevalence at risk. Therefore, use of rifabutin-based therapeutics should be judicial with accord to the local prevalence of tuberculosis. The hope for any new regimen is to yield eradication rates of more than 90\%; however, this also relies on patient adherence and compliance. Consequential to long term treatment, all regimens go with questionable adherence for the completion of the entire course. Dispensing drugs in patient-friendly plasticized convenience packs would improve patient adherence to the regimens. Framing a universally acceptable standard regimen is infeasible due to phylogeographic variations among the prevalent strains leading to wide distinctions in worldwide antimicrobial susceptibility (Yamaoka, 2010; Yamaoka et al., 2008). Availability of local surveillance data on regional susceptibility patterns can drive the implementation of nation-wide efficient management protocols for better therapeutic outcomes. Another barrier for eradication is the inaccessibility of antibiotic to all the niches of $H$. pylori due to the presence of bacteria along the mucosal surface and within the epithelial cells, which can be overcome by developing targeted delivery systems for transcellular and paracellular coverage.

\section{Tailored therapeutic regimens}

The current convention is to assess the antibiotic sensitivity of the pathogen following two courses of unsuccessful treatment (Malfertheiner et al., 2012). Exposure of the bacteria to sublethal doses of antibiotics for two relatively long courses may result in secondary resistance (Boltin et al., 2015) and so, pretreatment assessment of antibiotic susceptibility may be a superior option. Modalities for tailoring therapy can be made based on culture, susceptibility assessment by molecular methods, or pharmacogenomics. A systematic review comparing the results of 5 RCTs has established a baseline for culture-guided regimen over the standard regimen (Wenzhen et al., 2010) but conventional culture-sensitivity testing is invasive, time consuming, expensive, and unreliable as it does not accurately reflect the drug's in vivo activity (Gisbert et al., 2011). PCR and other PCR-based molecular techniques like restriction fragment length polymorphism (RFLP), DNA enzyme immunoassay (DEIA), oligonucleotide ligation assay (OLA), line probe assay (LPA), and real time PCR can be used to determine sensitivity (Lehours et al., 2011; M'egraud and Lehours, 2007; Schabereiter Grunter et al., 2004). For example, 23Sr RNA sequencing is done to assess clarithromycin susceptibility (Versalovic et al., 1996; Taylor et al., 1997). Molecular diagnostics can be run on traditional biopsy specimens and even on samples obtained by oro-gastric brush and gastric wash which are minimally invasive or stool samples, which are noninvasive (Kawai et al., 2008; Graham et al., 2005; Baba et al., 2011; Lottspeich et al., 2007). Moreover, these methods are time-saving when compared to conventional culture-sensitivity that consumes almost 10-14 days (7-10 days for culture, 2-4 days for sensitivity testing) and are more accurate. Fluorescent in situ hybridization (FISH) is another molecular method to detect the presence of resistant genotypes on wax-embedded sections (Yilmaz and Demiray, 2007; Yilmaz et al., 2007). Pharmacogenomic-based tailoring of anti-H. pylori treatment is done to optimize the action of PPIs by evaluating the activity of PPI-metabolizing microsomal enzyme CYP2C19, which is known to influence the action of other drugs (Goddard et al., 1996; Grayson et al., 1989; Sim et al., 2006; Furuta et al., 2001) and has been documented to yield better results when used as a parameter for tailoring along with clarithromycin susceptibility testing by molecular methods (Furuta et al., 2007). However, pharmacogenomics of CYP2C19 is only known to affect the metabolism of lansoprazole (Zhao et al., 2008) while other PPIs are not influenced (Lee et al., 2010; Pan et al., 2010). Development and promotion of simpler sampling techniques, rapid molecular drug sensitivity testing kits that are cost-effective and easily accessible, and PPI pharmacogenomics-based tailored drug regimens (Papastergiou et al., 2014) would be future aims.

\section{Probiotics and prebiotics}

Probiotics counteract the colonization and growth of pathogenic bacteria by releasing antibacterial substances, competing for receptor-binding sites, reinforcing the gut wall resistance, and modulating the immune response (Lesbros Pantoflickova et al., 2007). 
They also reduce the adverse effects of drug therapy (Papastergiou et al., 2014; Wilhelm et al., 2011). Supplementation of probiotics has recently garnered attention and has been found to be an effective adjuvant when administered with standard triple therapy ( Du et al., 2012), sequential regimen (Efrati et al., 2012), and levofloxacin-based regimens (Ojetti et al., 2012) but not with others (Manfredi et al., 2012, Shavakhi et al., 2013; Navarro Rodriguez et al., 2013). Lactobacillus spp., Bifidobacterium spp., B. clausii and Saccharomyces boulardii are few of the organisms that are known to have a beneficial role in H. pylori eradication (Shavakhi A et al, 2013). Lactobacillus spp. and Bifidobacterium spp. have been documented to be superior adjuvants with reference to multi-genera combinations in aiding $H$. pylori eradication and reducing adverse effects of antibiotics (Zheng et al., 2013; Zou et al., 2009; Wang et al., 2013). Saccharomyces boulardii supplementation reduced the incidence of antibiotic-induced diarrhea (Szajewska et al., 2010). Studies evaluating the effect of the addition of lactoferrin to probiotics concluded that addition of lactoferrin had no added advantages (de Bortoli et al., 2007). Though these suggest the beneficial effect of probiotic administration, efforts should be initiated to characterize the mechanisms of probiotic action to standardize the dose and frequency of administration and the incorporation of probiotics in the scheduled eradication regimens.

\section{Phage-directed elimination}

An ideal regimen would be one which discriminatingly kills only H. pylori. Bacteriophage-mediated elimination strategies are a novel modality which easily deals with the risk of antibiotic resistance (Ebinesh and Kailash, 2016). Being pathogen-specific, it results in selective elimination of all clones of $H$. pylori, including those which are drug resistant and those which are not. A major disadvantage of this strategy is the spontaneous development of bacterial resistance to phage infection which, if asphyxiated, can yield promising therapeutic modality for the management of any bacterial infection including $H$. pylori.

\section{Role of vaccines}

$H$. pylori vaccines have been proven to be beneficial in animal models. Human trials have not been initiated until now to establish their potency. Animal models have shown that infection with $H$. pylori induce Th1 cell response, causing inflammation that does not exhibit any kind of resistance to infection (Mohammadi et al., 1996). A healthy immune response requires the activation of Th2 cell-evoked immunity which can be elicited by using Th2 cell response-inducing adjuvants like cholera toxin and Freund's adjuvant. Evidence suggest that oral vaccination stimulates secretory IgA and serum Ig1 synthesis in mice (Ferrero et al., 1995; Kuipers et al., 2004). Successful efforts suggested the provocation of Th2 cell mediated cellular response and bacterial elimination following oral immunization with $H$. pylori urease in mice suffering from $\mathrm{H}$. felis infection (Saldinger et al., 1998). Hence, H. pylori vaccinations can prevent infection, cure an existing infection, and can also be used as adjuvants to antibiotic therapy (Corthesy Theulaz et al., 1996; Crabtree, 1998; Doidge et al., 1994; Ghiara et al., 1997; Hone and Hackett, 1989). Utilization of vaccines as an adjuvant to antibiotic therapy will reduce the bacterial load by $\mathrm{Th} 2$ cellmediated immune response and reduce the chances of nurturing drug resistance. All these interpretations have been made using the documented outcomes of the experiments on animal models. Accordingly, human trials should establish reliable information on the utility of vaccines in prevention and management of $H$. pylori infection (Johansson et al., 2004; Keller and Michetti, 2001; Michetti et al., 1999). H. pylori-associated diseases are prevalent in populations of low socioeconomic status, poor hygiene, and living conditions (Herbath et al., 2001; Woodward et al., 2000), the improvement of which would be the finest initiative for primordial prevention (Veldhuyzen van Zanten, 1995).

\section{CONCLUSION}

The main challenge for the eradication of $H$. pylori is the low gastric $\mathrm{pH}$, which instils survival benefits in the bacteria and reduces the bioavailability of antibiotic agents used for treatment. However, the newer drug regimens have a higher rate of absolute eradication. Tailored therapeutic regimens are effective if simpler sampling techniques and inexpensive molecular methods are introduced. Probiotic supplementation has relatively higher eradication rates but require standardization. Bacteriophage-mediated selective elimination of $H$. pylori is a promising innovation if ways to mitigate development of bacterial resistance are familiarized. Preventive and therapeutic oral vaccination provides high hopes if proven effective by clinical trials. A superior way of prevention would be to improve the environmental and sanitary conditions of human survival.

\section{REFERENCES}

Alekshun MN and Levy SB. Regulation of chromosomally mediated multiple antibiotic resistance: the mar regulon. Antimicrobial Agents and Chemotherapy (1997), 41, 2067-2075

Archer DL. Preservation microbiology and safety: evidence that stress enhances virulence and triggers adaptive mutations. Trends in Food Science and Technology. (1996), 7, 91-95

Atherton JC, Cockayne A, Balsitis M, Kirk GE, Hawkey CJ, Spiller RC. Detection of the intragastric sites at which Helicobacter pylori evades treatment with amoxicillin and cimetidine. Gut (1995), 36, 670-674

Axon ATR. Helicobacter pylori: effect on peptic ulcer disease. Journal of Gastroenterology and Hepatology (1991), 6, 131-37

Baba S, Oishi Y, Watanabe Y, Oikawa R, Morita R, Yoshida Y, Hiraishi T, Maehata T, Nagase Y, Fukuda Y, Nakazawa M, Ishigouoka S, Hattori N, Suzuki H, Toyota M, Niwa H, Suzuki M, Itoh F. Gastric wash-based molecular testing for antibiotic resistance in Helicobacter pylori. Digestion (2011), 84, 299-305

Basu PP, Rayapudi K, Pacana T, Shah N J, Krishnaswamy N, Flynn M. A randomized study comparing levofloxacin, omeprazole, nitazoxanide, and doxycycline versus triple therapy for the eradication of Helicobacter pylori. American Journal of Gastroenterology (2011), 106, 1970-1975

Bijlsma JJ, Lie LMN, Nootenboom IC, Vandenbroucke-Grauls CM, and Kusters JG. Identification of loci essential for the growth of Helicobacter pylori under acidic conditions. Journal of Infectious Diseases (2000), 182, 1566-1569

Bizzozero, G. Ueber die schlauchfo"rmigen Drüsen des Magendarmkanals und die Beziehungen ihres Epithels zu dem Oberfla“chenepithel der Schleimhaut. Dritte mitteilung. Archiv fur Mikroskopische Anatomie (1893), 43, 82-152

Bloom SR, Polak JM. Physiology of gastrointestinal hormones. Biochemical Society Transactions (1980), 8, 15-17

Boltin D, et al. Trends in Secondary Antibiotic Resistance of Helicobacter pylori from 2007 to 2014: Has the Tide Turned? Journal of Clinical Microbiology 
(2015), 53, 522-527

Börsch GM, Graham DY. Helicobacter pylori. Pharmacology of peptic ulcer disease. In: Collen MJ, Benjamin SB, eds. Handbook of experimental pharmacology. Volume 99. Berlin: Springer-Verlag, 1991:107-148

Bremer E and Krämer R. 2000. Coping with osmotic challenges: osmoregulation through accumulation and release of compatible solutes in bacteria, p. 79-97. In G. Storz and R. Hengge-Aronis (ed.), Bacterial stress responses. ASM Press, Washington, DC.

Broutet N, Tchamgoue S, Pereira E, Lamouliatte H, Salamon R, Megraud F. Risk factors for failure of Helicobacter pylori therapy - results of an individual data analysis of 2751 patients. Alimentary Pharmacology and Therapeutics (2003), 17, 99-109

Burne RA and Chen YM. Bacterial ureases in infectious diseases. Microbes and Infection (2000), 2, 533-542

Chey WD, Wong BCY. American College of Gastroenterology guideline on the management of Helicobacter pylori infection. American Journal of Gastroenterology (2007), 102, 1808-1825

Chuah SK, Tsay FW, Hsu PI, Wu DC. A new look at anti-Helicobacter pylori therapy. World Journal of Gastroenterology (2011), 17, 3971-3975

Corthesy-Theulaz I, Porta N, Pringault E, Racine L, Bogdanova A, Kraehenbuhl JP, Blum AL, Michetti P. Adhesion of Helicobacter pylori to polarized T84 human intestinal cell monolayers is $\mathrm{pH}$ dependent. Infection and Immunity (1996), 64, 3827-3832

Crabtree JE. Eradication of chronic Helicobacter pylori infection by therapeutic vaccination. Gut (1998), 43, 7-8

de Bortoli N, Leonardi G, Ciancia E, Merlo A, Bellini M, Costa F, Mumolo MG, Ricchiuti A, Cristiani F, Santi S, Rossi M, Marchi S. Helicobacter pylori eradication: a randomized prospective study of triple therapy versus triple therapy plus lactoferrin and probiotics. American Journal of Gastroenterology (2007), 102, 951-956

Doidge C, Gust I, Lee A, Buck F, Hazell S, Manne U. Therapeutic immunisation against helicobacter infection. Lancet (1994), 343, 914-915

Du YQ, Su T, Fan JG, Lu YX, Zheng P, Li XH, Guo CY, Xu P, Gong YF, Li ZS. Adjuvant probiotics improve the eradication effect of triple therapy for Helicobacter pylori infection. World Journal of Gastroenterology (2012), 18, 63026307

Ebinesh A and Kailash TV. Bacteriophage-mediated microbiome manipulation: A novel venture in fostering infant gut health. International Journal of Medical Biotechnology and Genetics (2016), 4, 34-39

Ebinesh A and Kailash TV. Looking into antibiotic failure: Deemed a threat, indeed not. International Journal of Applied Research Studies (2016), 5

Ebinesh A, Vijaykumar GS et al. Exposure to stress minimizes the zone of antimicrobial action: A phenotypic demonstration with six Acinetobacter baumanni strains. MicroMedcine (2016), 6, 16-35

Efrati C, Nicolini G, Cannaviello C, O'Sed NP, Valabrega S. Helicobacter pylori eradication: sequential therapy and Lactobacillus reuteri supplementation. World Journal of Gastroenterology (2012), 18, 6250-6254

Engstrand L, Graham DY, Schelnius A, Genta RM, El-Zaatari FAK. Is the sanctuary where Helicobacter pylori avoids antibacterial treatment intracellular? American Journal of Clinical Pathology (1997), 108, 504-509

Ferrero RL, Thiberge JM, Kansau I, Wuscher N, Huerre M, Labigne A. The GroES homolog of Helicobacter pylori confers protective immunity against mucosal infection in mice. Proceedings of National Academy of Sciences of the USA (1995), 92, 6499-6503

Francesco VD, et al. Worldwide $H$. pylori antibiotic resistance: a systematic review. Journal of Gastrointestinal and Liver Diseases (2010), 19, 409-414

Friedrich MJ. Microbiome project seeks to understand human body's microscopic residents. JAMA (2008), 300, 777-778

Furuta T, Shirai N, Kodaira M, Sugimoto M, Nogaki A, Kuriyama S, Iwaizumi M, Yamade M, Terakawa I, Ohashi K, Ishizaki T, Hishida A. Pharmacogenomics-based tailored versus standard therapeutic regimen for eradication of H. pylori. Clinical Pharmacology Therapeutics (2007), 81, 521-528

Furuta T, Shirai N, Takashima M, Xiao F, Hanai H, Sugimura H, Ohashi K, Ishizaki T, Kaneko E. Effect of genotypic differences in CYP2C19 on cure rates for Helicobacter pylori infection by triple therapy with a proton pump inhibitor, amoxicillin, and clarithromycin. Clinical Pharmacology Therapeutics
(2001), 69, 158-168

Genta RM, Huberman RM, Graham DY. The gastric cardia in Helicobacter pylori infection. Human Pathology (1994), 25, 915-919

Ghiara P, Rossi M, Marchetti M, Di Tommaso A, Vindigni C, Ciampolini F, Covacci A, Telford JL, De Magistris MT, Pizza M, Rappuoli R, Del Giudice G. Therapeutic intragastric vaccination against Helicobacter pylori in mice eradicates an otherwise chronic infection and confers protection against reinfection. Infection and Immunity (1997), 65, 4996-5002

Gisbert JP. Is culture necessary before first-line treatment for Helicobacter pylori infection? Internal Medicine (2011), 50, 2717; author reply 2719-2720

Gisbert JP, Calvet X, O'Connor A, M'egraud F, O'Morain CA. Sequential therapy for Helicobacter pylori eradication: a critical review. Journal of Clinical Gastroenterology (2010), 44, 313-325

Glocker E, Bogdan C, Kist M. Characterization of rifampicin-resistant clinical Helicobacter pylori isolates from Germany. Journal of Antimicrobial Chemotherapy (2007), 59, 874-879

Goddard AF, Jessa MJ, Barrett DA, Shaw PN, Idström JP, Cederberg C, Spiller RC. Effect of omeprazole on the distribution of metronidazole, amoxicillin, and clarithromycin in human gastric juice. Gastroenterology (1996), 111, 358-367

Goodwin CS, Armstrong JA, Chilvers T, Peters M, Colins MD, Sly L, McConnell W, Harper WES. Transfer of Campylobacter pylori and Campylobacter mustelae to Helicobacter gen. nov. as Helicobacter pylori comb. nov. and Helicobacter mustelae comb. nov., respectively. International Journal of Systemic Bacteriology (1989), 39, 397-405

Graham DY. Antibiotic resistance in H. pylori: Implications for therapy. Gastroenterology (1998), 115, 1272-1277

Graham DY, Börsch GM. The who's and when's of therapy for Helicobacter pylori. American Journal of Gastroenterology (1990), 85, 1552-1555

Graham DY, Evans DG. Prevention of diarrhea caused by enterotoxigenic Escherichia coli: lessons learned with volunteers. Reviews of Infectious Diseases (1990), 12:1, S68-S72

Graham DY, Fischbach L. Helicobacter pylori treatment in the era of increasing antibiotic resistance. Gut (2010), 59, 1143-1153

Graham DY, Kudo M, Reddy R, Opekun AR. Practical rapid, minimally invasive, reliable nonendoscopic method to obtain Helicobacter pylori for culture. $\mathrm{He}$ licobacter (2005), 10, 1-3

Graham DY, Lu H, Yamaoka H. African, Asian or Indian enigma, the East Asian Helicobacter pylori: facts or medical myths. Journal of Digestive Diseases (2009), 10, 77-84

Grant R, Grossman MI, Ivy AC. Histological changes in the gastric mucosa during digestion and their relationship to mucosal growth. Gastroenterology (1953), $25,218-231$

Grayson ML, Eliopoulos GM, Ferraro MJ, Moellering RC. Effect of varying pH on the susceptibility of Campylobacterpylori to antimicrobial agents. European Journal of Clinical Microbiology and Infectious Diseases (1989), 8, 888-889

Grayson ML, Eliopoulos GM, Ferraro MJ, Moellering RC Jr. Effect of varying pH on the susceptibility of Campylobacter pylori to antimicrobial agents. European Journal of Clinical Microbiology and Infectious Diseases (1989), 8, $888-889$

Goodwin CS, McNulty CAM. Bacteriological and pharmaceutical basis for the treatment of Helicobacter pylori infection. In: Rathbone B, Vealtley V, eds. Helicobacter pylori and gastrointestinal disease. 2nd ed. London: Blackwell Scientific, 1992, 224-231

Hastings PJ, Rosenberg SM, Slack A. Antibiotic-induced lateral transfer of antibiotic resistance. Trends in Microbiology (2004), 12, 401-404

Heep M, Beck D, Bayerdörffer E, Lehn N. Rifampin and rifabutin resistance mechanism in Helicobacter pylori. Antimicrobial Agents and Chemotherapy (1999), 43, 1497-1499

Herbarth O, Krumbiegel P, Fritz GJ, Richter M, Schlink U, Muller DM, Richter T. Helicobacter pylori prevalences and risk factors among school beginners in a German urban center and its rural county. Environmental Health Perspectives (2001), 109, 573-577

Hoffman JSC, David R. Treatment of Helicobacter pylori. Current Opinion in Gastroenterology (2001), 17, 30-34

Hone, D., and J. Hackett. Vaccination against enteric bacterial diseases. Reviews of 
Infectious Diseases (1989), 11, 853-877

Hunt RH. Hp and pH: implications for the eradication of Helicobacter pylori. Scandinavian Journal of Gastroenterology. Suppl. 1993; 196:12-16

Hunt RH, Falcone CA, Thomson AB. Canadian Helicobacter study group. Canadian Helicobacter pylori consensus conference update: infections in adults. Canadian Journal of Gastroenterology (1999), 13, 213-217

Hsu PI, Wu DC, Chen A, et al. Quadruple rescue therapy for Helicobacter pylori infection after two treatment failures. European Journal of Clinical Investigation (2008), 38, 404-409

Hsu PI, Wu DC, Wu JY, Graham DY. Modified Sequential Helicobacter pylori therapy: proton pump inhibitor and amoxicillin for 14 days with clarithromycin and metronidazole added as a quadruple (hybrid) therapy for the final 7 days. Helicobacter (2011), 16, 139-145

Johansson EL, Bergquist C, Edebo A, Johansson C, Svennerholm AM. Comparison of different routes of vaccination for eliciting antibody responses in the human stomach. Vaccine (2004), 22, 984-990

Jolivet-Gougeon A, David-Jobert S, Tamanai-Shacoori Z, Menard C, and Cormier M. Osmotic stress-induced genetic rearrangements in Escherichia coli H10407 detected by randomly amplified polymorphic DNA analysis. Applied and Environmental Microbiology (2000), 66, 5484-5487

Kalebi A, Rana F, Mwanda W, Lule G, Hale M. Histopathological profile of gastritis in adult patients seen at a referral hospital in Kenya. World Journal of Gastroenterology (2007), 13, 4117-4121

Kawai T, Yamagishi T, Yagi K, Kataoka M, Kawakami K, Sofuni A, Itoi T, Sakai Y, Moriyasu F, Osaka Y, Takagi Y, Aoki T, Rimbara E, Noguchi N, Sasatsu M. Tailored eradication therapy based on fecal Helicobacter pylori clarithromycin sensitivities. Journal of Gastroenterology and Hepatology (2008), 23:2, S171-S174

Keller WC and Michetti P. Vaccination against Helicobacter pylori-an old companion of man. Expert Opinion on Biological Therapy (2001), 1, 795-802

Kreiss C, Buclin T, Cosma M, Corthesy-Theulaz I, Michetti P. Safety of oral immunisation with recombinant urease in patients with Helicobacter pylori infection. Lancet (1996), 347, 1630-1631

Kuipers EJ. Helicobacter pylori and the risk and management of associated diseases: gastritis, ulcer disease, atrophic gastritis, and gastric cancer. Alimentary Pharmacology and Therapeutics (1997), 11:1,71-88

Kuipers EJG, Nelis F, Klinkenberg-Knol EC, Snel P, Goldfain D, Kolkman JJ, Festen HPM, Dent J, Zeitoun P, Havu N, Lamm M, Walan A. Cure of Helicobacter pylori infection in patients with reflux oesophagitis treated with longterm omeprazole reverses gastritis without exacerbation of reflux disease: results of a randomised controlled trial. Gut (2004), 53, 12-20

Kusters JG. Pathogenesis of Helicobacter pylori infection. Clinical Microbiology Reviews (2006), 19, 449-90

Laine L, Hunt R, EI-Zimaity H, Nguyen B, Osato M, Sp'enard J. Bismuth-based quadruple therapy using a single capsule of bismuth biskalcitrate, metronidazole, and tetracycline given with omeprazole versus omeprazole, amoxicillin, and clarithromycin for eradication of Helicobacter pylori in duodenal ulcer patients: a prospective, randomized, multicenter, North American trial. American Journal of Gastroenterology (2003), 98, 562-567

Lee VW, Chau TS, Chan AK, Lee KK, Waye MM, Ling TK, Chan FK. Pharmacogenetics of esomeprazole or rabeprazole- based triple therapy in Helicobacter pylori eradication in Hong Kong non-ulcer dyspepsia Chinese subjects. Journal of Clinical Pharmacology and Therapeutics (2010), 35, 343-350

Lehours P, Siffré E, Mégraud F. DPO multiplex PCR as an alternative to culture and susceptibility testing to detect Helicobacter pylori and its resistance to clarithromycin. BMC Gastroenterology (2011), 11, 112

Lesbros-Pantoflickova D, Corthésy-Theulaz I, Blum AL. Helicobacter pylori and probiotics. Journal of Nutrition (2007), 137, 812S-818S

Liou JM, Lin JT, Chang CY et al. Levofloxacin-based and clarithromycin-based triple therapies as first-line and secondline treatments for Helicobacter pylori infection: a randomized 8 Gastroenterology Research and Practice comparative trial with crossover design. Gut (2010), 59, 572-578

Lottspeich C, Schwarzer A, Panthel K, Koletzko S, Rüssmann H. Evaluation of the novel Helicobacter pylori Clari- Res real-time PCR assay for detection and clarithromycin susceptibility testing of $H$. pylori in stool specimens from symptomatic children. Journal of Clinical Microbiology (2007), 45, 1718-
1722

Ma D, Cook DN, Alberti M, Pon NG, Nikaido H, Hearst JE. Genes Acra and Acrb encode a stress-induced efflux system of Escherichia coli. Molecular Microbiology (1995), 16, 45-55

Malfertheiner P, Bazzoli F, Delchier JC et al. Helicobacter pylori eradication with a capsule containing bismuthsubcitrate potassium, metronidazole, and tetracycline given with omeprazole versus clarithromycin-based triple therapy: a randomised, open-label, non-inferiority, phase 3 trial." Lancet (2011), 377, 905-913

Malfertheiner P, Chan FK, McColl KE. Peptic ulcer disease. Lancet (2009), 374, 1449-1461. doi:10.1016/ S0140-6736(09)60938-7

Malfertheiner P, Megraud F, O'Morain C et al. Current concepts in the management of Helicobacter pylori infection - The Maastricht 2-2000 Consensus Report. Alimentary Pharmacology and Therapeutics (2002), 16, 167-80.

Malfertheiner P, Megraud F, O'Morain C et al. Current concepts in the management of Helicobacter pylori infection: the Maastricht III Consensus Report. Gut (2007), 56, 772-781

Malfertheiner P, Megraud F, O'Morain CA et al. Management of Helicobacter pylori infection - the Maastricht IV/ Florence consensus report. Gut (2012) $61,646-664$

Manfredi M, Bizzarri B, Sacchero RI, Maccari S, Calabrese L, Fabbian F, De'Angelis GL. Helicobacter pylori infection in clinical practice: probiotics and a combination of probiotics + lactoferrin improve compliance, but not eradication, in sequential therapy. Helicobacter (2012), 17, 254-263

Marshall BJ. Treatment strategies for Helicobacter pylori infection. Gastroenterology Clinics of North America (1993), 22, 183-198

Marshall BJ, Armstrong JA, Francis GJ, Nokes NT, Wee SH. Antibacterial action of bismuth in relation to Campylobacter pyloridis colonization and gastritis. $\mathrm{Di}$ gestion (1987), 37:2, 16-30

Marshall BJ, Armstrong JA, McGechie DB, Glancy RJ. Attempt to fulfil Koch's postulates for pyloric Campylobacter. Medical Journal of Australia (1985), $142,436-439$

Marshall BJ, McGechie DB, Rogers PA, Glancy RJ. Pyloric campylobacter infection and gastroduodenal disease. Medical Journal of Australia (1985), $142,439-444$

Marshall BJ and Warren JR. Unidentified curved bacilli in the stomach of patients with gastritis and peptic ulceration. Lancet (1984), i:1311-1315

Mbulaiteye SM, Hisada M, El-Omar EM. Helicobacter Pylori associated global gastric cancer burden. Frontiers in Bioscience (Landmark Ed; 2009), 14, 1490-1504. doi: $10.2741 / 3320$

McDowell DA. 2004. Food processing stresses in the spread of antibiotic resistance, p. 243-265. In F. J. M. Smulders and J. D. Collins (ed.), Safety assurance during food processing: food safety assurance and veterinary public health, vol. 2. Wageningen Academic Publishers, Wageningen, The Netherlands.

McLauchlan et al. Comparison of gastric body and antral pH: a 24 hour ambulatory study in healthy volunteers. Gut (1989), 30, 573-578.

McMahon MAS, Xu J, et al. Environmental stress and antibiotic resistance in foodrelated pathogens. Applied and Environmental Microbiology (2007), 211-217

Mégraud F. H. pylori antibiotic resistance: prevalence, importance, and advances in testing. Gut (2004), 53, 1374- 1384

Mégraud F, Lehours P. Helicobacter pylori detection and antimicrobial susceptibility testing. Clinical Microbiology Reviews (2007), 20, 280-322

Mégraud F, Lehours P. Helicobacter pylori detection and antimicrobial susceptibility testing. Clinical Microbiology Reviews (2007), 20, 280-322

Mégraud F, Trimoulet P, Lamouliatte H, Boyanova L. Bactericidal effect of amoxicillin on Helicobacter pylori in an in vitro model using epithelial cells. Antimicrobial Agents and Chemotherapy (1991), 35, 869-872

Michetti P, Kreiss C, Kotloff KL, Porta N, Blanco JL, Bachmann D, Herranz M, Saldinger PF, Corthesy-Theulaz I, Losonsky G, Nichols R, Simon J, Stolte M, Ackerman S, Monath TP, Blum AL. Oral immunization with urease and Escherichia coli heat-labile enterotoxin is safe and immunogenic in Helicobacter pylori-infected adults. Gastroenterology (1999), 116, 804-812

Midolo PD, Turnidge JD, Munkhof WJ, Berry V, Woodnutt G. Is bactericidal activity of amoxicillin against Helicobacter pylori concentration dependent? Antimicrobial Agents and Chemotherapy (1996), 40, 1327-1328 
Mohammadi M, Czinn S, Redline R, Nedrud J. Helicobacterspecific cell-mediated immune responses display a predominant Th1 phenotype and promote a delayed-type hypersensitivity response in the stomachs of mice. Journal of Immunology (1996), 156, 4729-4738

Morris AJ, Ali MR, Nicholson GI, Perez-Perez GI, Blaser MJ. Long-term followup of voluntary ingestion of Helicobacter pylori. Annals of Internal Medicine (1991), 114, 662-663

Morris A and Nicholson G. Ingestion of Campylobacter pyloridis causes gastritis and raised fasting gastric pH. American Journal of Gastroenterology (1987), $82,192-199$

Moayyedi P, Sahay P, Tompkins DS, Axon ATR. Efficacy and optimum dose of omeprazole in a new 1- week triple therapy regimen to eradicate Helicobacter pylori. European Journal of Gastroenterology and Hepatology (1995), 7, $835-840$

Navarro-Rodriguez T, Silva FM, Barbuti RC, Mattar R, Moraes-Filho JP, de Oliveira MN, Bogsan CS, Chinzon D, Eisig JN. Association of a probiotic to a Helicobacter pylori eradication regimen does not increase efficacy or decreases the adverse effects of the treatment: a prospective, randomized,doubleblind, placebo-controlled study. BMC Gastroenterology (2013), 13, 56

Necchi V, Candusso ME, Tava F et al. Intracellular, intercellular, and stromal invasion of gastric mucosa, preneoplastic lesions, and cancer by Helicobacter pylori. Gastroenterology (2007), 132, 1009-1023

Nishizawa T, Suzuki H, Hibi T. Quinolone-based thirdline therapy for Helicobacter pylori eradication. Journal of Clinical Biochemistry and Nutrition (2009), $44,119-124$

Ojetti V, Bruno G, Ainora ME, Gigante G, Rizzo G, Roccarina D, Gasbarrini A. Impact of Lactobacillus reuteri. Supplementation on Anti-Helicobacter pylori Levofloxacin-Based Second-Line Therapy. Gastroenterology Research and Practice (2012), 740381. doi:10.1155/2012/740381

O'Morain C, Borody T, Farley A et al. Efficacy and safety of single-triple capsules of bismuth biskalcitrate, metronidazole and tetracycline, given with omeprazole, for the eradication of Helicobacter pylori: an international multicentre study. Alimentary Pharmacology and Therapeutics (2003), 17, 415-420

Pan X, Li Y, Qiu Y, Tang Q, Qian B, Yao L, Shi R, Zhang G. Efficacy and tolerability of first-line triple therapy with levofloxacin and amoxicillin plus esomeprazole or rabeprazole for the eradication of Helicobacter pylori infection and the effect of CYP2C19 genotype: a 1-week, randomized, open label study in Chinese adults. Clinical Therapeutics (2010), 32, 2003-2011

Papastergiou V, Georgopoulos SD, Karatapanis S. Treatment of Helicobacter pylori infection: Meeting the challenge of antimicrobial resistance. World Journal of Gastroenterology (2014), 20, 9898-9911

Pel PK. Diseases of the stomach. 1899. De Erven Bohn, Amsterdam, The Netherlands

Perez Aldana L, Kato M, Nakagawa S et al. The relationship between consumption of antimicrobial agents and the prevalence of primary Helicobacter pylori resistance. Helicobacter (2002), 7, 306-309

Phillips RH, Whitehead MW, Doig LA et al. Is eradication of Helicobacter pylori with colloidal Bismuth subcitrate quadruple therapy safe? Helicobacter (2001), 6, 151-156

Rauwss EAJ and Tytgat GNJ. Cure of duodenal ulcer associated with eradication of Helicobacter pylori. Lancet (1990), 335, 1233-35

Rowan NJ. Evidence that inimical food-preservation barriers alter microbial resistance, cell morphology and virulence. Trends in Food Science and Technology (1999), 10, 261-270

Saldinger PF, Porta N, Launois P, Louis JA, Waanders GA, Bouzourene H, Michetti $\mathrm{P}$, Blum AL, Corthesy-Theulaz IE. Immunization of BALB/c mice with Helicobacter urease B induces a T helper 2 response absent in Helicobacter infection. Gastroenterology (1998), 115, 891-897

Schabereiter-Gurtner C, Hirschl AM, Dragosics B, Hufnagl P, Puz S, Kovách Z, Rotter M, Makristathis A. Novel real-time PCR assay for detection of Helicobacter pylori infection and simultaneous clarithromycin susceptibility testing of stool and biopsy specimens. Journal of Clinical Microbiology (2004), 42, 4512-4518

Schade C, Flemstrom G, Holm L. Hydrogen ion concentration in the mucus layer on top of acid-stimulated and -inhibited rat gastric mucosa. Gastroenterology (1994), 107, 180-188
Schistosomes, liver flukes, and Helicobacter pylori. IARC Working Group on the Evaluation of Carcinogenic Risks to Humans. Lyon, 7-14 June 1994. IARC Monograph on the Evaluation of Carcinogenic Risks to Humans (1994), 61: 1-241

Schreiber S, Konradt M, Groll C, Scheid P, Hanauer G, Werling HO, Josenhans C, Suerbaum S. The spatial orientation of Helicobacter pylori in the gastric mucus. Proceedings of National Academy of Sciences of USA (2004), 101, 5024-5029

Scott D, Weeks D, Melchers K, Sachs G. The life and death of Helicobacter pylori. Gut (1998), 43, S56-S60

Shavakhi A, Tabesh E, Yaghoutkar A, Hashemi H, Tabesh F, Khodadoostan M, Minakari M, Shavakhi S, Gholamrezaei A. The effects of multistrain probiotic compound on bismuth-containing quadruple therapy for Helicobacter pylori infection: a randomized placebo-controlled triple-blind study. Helicobacter (2013), 18, 280-284

Sim SC, Risinger C, Dahl ML, Aklillu E, Christensen M, Bertilsson L, IngelmanSundberg M. A common novel CYP2C19 gene variant causes ultrarapid drug metabolism relevant for the drug response to proton pump inhibitors and antidepressants. Clinical Pharmacology Therapeutics (2006), 79, 103-113

Stingl K, Altendorf K, and Bakker EP. Acid survival of Helicobacter pylori: how does urease activity trigger cytoplasmic $\mathrm{pH}$ homeostasis? Trends in Microbiology (2002), 10, 70-74

Suzuki S, Suzuki H, Nishizawa T et al. Past rifampicin dosing determines rifabutin resistance of Helicobacter pylori. Digestion (2009), 79, 1-4

Szajewska H, Horvath A, Piwowarczyk A. Meta-analysis: the effects of Saccharomyces boulardii supplementation on Helicobacter pylori eradication rates and side effects during treatment. Alimentary Pharmacology and Therapeutics (2010), 32, 1069-1079

Taylor DE, Ge Z, Purych D, Lo T, Hiratsuka K. Cloning and sequence analysis of two copies of a 23S rRNA gene from Helicobacter pylori and association of clarithromycin resistance with $23 \mathrm{~S}$ rRNA mutations. Antimicrobial Agents and Chemotherapy (1997), 41, 2621-2628

Testerman TL and Morris J. Beyond the stomach: An updated view of Helicobacter pylori pathogenesis, diagnosis, and treatment. World Journal of Gastroenterology (2014), 20:36, 12781-12808

Toracchio S, Capodicasa S, Soraja DB, Cellini L, Marzio L. Rifabutin based triple therapy for eradication of $H$. pylori primary and secondary resistant to tinidazole and clarithromycin. Digestive and Liver Disease (2005), 37, 33-38

Unge P, Gad A, Gnarpe H, Olsson J. Does omeprazole improve antimicrobial therapy directed towards gastric Campylobacter pylori in patients with antral gastritis? A pilot study. Scandinavian Journal of Gastroenterology (1989), 24:167, 49-54

Vakil N, Megraud F. Eradication therapy for Helicobacter pylori. Gastroenterology (2007), 133, 985-1001

Van Der Poorten D, Katelaris PH. The effectiveness of rifabutin triple therapy for patients with difficult-to-eradicate Helicobacter pylori in clinical practice. Alimentary Pharmacology and Therapeutics (2007), 26, 1537-1542

Veldhuyzen van Zanten SJ. Do socio-economic status, marital status and occupation influence the prevalence of Helicobacter pylori infection? Alimentary Pharmacology and Therapeutics (1995), 9:2, 41-44

Velkov VV. How environmental factors regulate mutagenesis and gene transfer in microorganisms. Journal of Biosciences (1999), 24, 529-559

Versalovic J, Shortridge D, Kibler K, Griffy MV, Beyer J, Flamm RK, Tanaka SK, Graham DY, Go MF. Mutations in 23S rRNA are associated with clarithromycin resistance in Helicobacter pylori. Antimicrobial Agents and Chemotherapy (1996), 40, 477-480

Wang ZH, Gao QY, Fang JY. Meta-analysis of the efficacy and safety of Lactobacillus-containing and Bifido bacterium containing probiotic compound preparation in Helicobacter pylori eradication therapy. Journal of Clinical Gastroenterology (2013), 47, 25-32

Warren JR and Marhsall BJ. Unidentified curved bacilli on gastric epithelium in active chronic gastritis. Lancet (1983), i:1273-1275

Wenzhen Y, Yumin L, Quanlin G, Kehu Y, Lei J, Donghai W, Lijuan Y. Is antimicrobial susceptibility testing necessary before first-line treatment for Helicobacter pylori infection? Meta-analysis of randomized controlled trials. Internal Medicine (2010), 49, 1103-1109 
Willems G. Trophicity of gastric epithelium and its regulation. In: Mignon M, Galmiche J-P, eds. Safe and effective control of acid secretion. Paris: John Libbey Eurotext, 1988:39-50

Wilhelm SM, Johnson JL, Kale-Pradhan PB. Treating bugs with bugs: the role of probiotics as adjunctive therapy for Helicobacter pylori. Annals of Pharmacotherapy (2011), 45, 960-966

Woodward M, Morrison C, McColl K. An investigation into factors associated with Helicobacter pylori infection. Journal of Clinical Epidemiology (2000), 53, $175-181$

Wu DC, Hsu PI, Wu JY et al. Sequential and concomitant therapy with four drugs is equally effective for eradication of $\mathrm{H}$ pylori infection. Clinical Gastroenterology and Hepatology (2010), 8, 36-41. e1

$\mathrm{Wu} \mathrm{W}$, Yang $\mathrm{Y}$ et al. Recent insights into antibiotic resistance in Helicobacter pylori eradication. Gastroenterology Research and Practice (2012). doi:10.1155/2012/723183

Yamaoka Y, Kato M, Asaka M. Geographic differences in gastric cancer incidence can be explained by differences between Helicobacter pylori strains. Internal Medicine (2008), 47, 1077-1083

Yamaoka Y. Mechanisms of disease: Helicobacter pylori virulence factors. Nature Reviews Gastroenterology and Hepatology (2010), 7, 629-641

Yilmaz O, Demiray E. Clinical role and importance of fluorescence in situ hybridization method in diagnosis of $\mathrm{H}$ pylori infection and determination of clarithromycin resistance in $\mathrm{H}$ pylori eradication therapy. World Journal of Gastroenterology (2007), 13, 671-675

Yilmaz O, Demiray E, Tümer S, Altungöz O, Yörükoğlu K, Soytürk M, Simşek I. Detection of Helicobacter pylori and determination of clarithromycin susceptibility using formalinfixed, paraffin-embedded gastric biopsy specimens by fluorescence in situ hybridization. Helicobacter (2007), 12, 136-141

Zhao F, Wang J, Yang Y, Wang X, Shi R, Xu Z, Huang Z, Zhang G. Effect of CYP2C19 genetic polymorphisms on the efficacy of proton pump inhibitorbased triple therapy for Helicobacter pylori eradication: a meta-analysis. $\mathrm{He}$ licobacter (2008), 13, 532-541

Zheng X, Lyu L, Mei Z. Lactobacillus-containing probiotic supplementation increases Helicobacter pylori eradication rate: evidence from a meta-analysis. Revista Espanola de Enfermedades Digestivas (2013), 105, 445-453

Zou J, Dong J, Yu X. Meta-analysis: Lactobacillus containing quadruple therapy versus standard triple first-line therapy for Helicobacter pylori eradication. Helicobacter (2009), 14, 97-107 